\title{
Proceedings of the Institution of Civil Engineers 2004: Bridge Engineering, vol. 157
}

\section{Subject index}

Anchors $\mathrm{Ct}$ anchorages

Strengthening rail bridge wingwalls for containment barriers.

Clubley S. K. and Morey M. E. J. Sep., 163-170

\section{Beams \&t girders}

Design of the New Medway Bridge, England. Smith D. A. and Hendy C. R. Mar., 27-36

\section{Bearings}

Bearings for the M2 New Medway Bridge. Boulton P. and Tomaselli F. Jun., 65-70

\section{Bridges}

Assessment testing Mizen Head Footbridge, Ireland. Ruane K. D. and Healy A. Sep., 117-122

Bearings for the M2 New Medway Bridge. Boulton P. and Tomaselli F. Jun., 65-70

Behaviour of post-tensioned concrete box girders. Lark R. J., Howells R. W. and Barr B. I. G. Jun., 71-81

Comparison of slab-bridge safety assessment strategies. Imhof D. and Middleton C. R. Sep., 147-155

Design and construction of Tongwamen Bridge, China. Zhang Z., Pan S.-S. and Huang C.-L. Mar., 1-7

Design of Garrion Bridge, Scotland. Fleck J., Chalmers B. and Todd D. Mar., 19-26

Design of the New Medway Bridge, England. Smith D. A. and Hendy C. R. Mar., 27-36

Development of Eirspan: Ireland's bridge management system. Duffy L. Sep., 139-146

Evaluation of localised loading on suspension bridges. Wyatt T. A. Jun., 55-63

HSFG bolted connections using weathering steel materials.

Lark R. J. Jun., 103-110

Llangollen Railway: refurbishment of Berwyn Viaduct. Symonds J. D. Sep., 151-161

New bridge technology for sustainable development. Head P. R. Dec., 193-202

Performance of repairs to concrete bridges. Tilly G. P. Sep., $171-174$

Portrack, Scotland-a major railway realignment. Hackney M. J., Stocks A., Miller K. and Jencks C. Dec., 177-186

Seismic design of Egnatia Motorway bridges, Greece. AhmadiKashani K. Jun., 83-91

Strengthening fatigue-cracked steel bridge decks. Battista R. C. and Pfeil M. S. Jun., 93-102

Strengthening rail bridge wingwalls for containment barriers. Clubley S. K. and Morey M. E. J. Sep., 163-170

The refurbishment of Heyeswood Railway Bridge. Dixon R. Sep., 131-137

The Tay Rail Bridge disaster revisited. Martin T. and MacLeod I. A. Dec., 187-192

Value of shock transmission units for Mumbai Bridge. Patel D. J. Dec., 203-212
Whole life cost analysis in concrete bridge tender evaluation. Arya C. and Vassie P. R. Mar., 9-18

Composite structures

New bridge technology for sustainable development. Head P. R. Dec., 193-202

\section{Concrete}

Performance of repairs to concrete bridges. Tilly G. P. Sep., $171-174$

\section{Concrete structures}

Assessment testing Mizen Head Footbridge, Ireland. Ruane K. D. and Healy A. Sep., 117-122

Behaviour of post-tensioned concrete box girders. Lark R. J., Howells R. W. and Barr B. I. G. Jun., 71-81

Design and construction of Tongwamen Bridge, China. Zhang Z., Pan S.-S. and Huang C.-L. Mar., 1-7

Design of Garrion Bridge, Scotland. Fleck J., Chalmers B. and Todd D. Mar., 19-26

Design of the New Medway Bridge, England. Smith D. A. and Hendy C. R. Mar., 27-36

Strengthening concrete structures using fibre composites. Darby A., Ibell T., Clarke J., Denton S., Farmer N. and Luke S. Sep., 123-129

Cranes, structures $\mathrm{Ct}$ elements

Portrack, Scotland-a major railway realignment. Hackney M. J., Stocks A., Miller K. and Jencks C. Dec., 177-186

Economics \&t finance

Whole life cost analysis in concrete bridge tender evaluation. Arya C. and Vassie P. R. Mar., 9-18

Failures

Performance of repairs to concrete bridges. Tilly G. P. Sep., 171-174

The Tay Rail Bridge disaster revisited. Martin T. and MacLeod I. A. Dec., 187-192

Fatigue cracks

Strengthening fatigue-cracked steel bridge decks. Battista R. C. and Pfeil M. S. Jun., 93-102

Fibre-reinforced polymers

Strengthening concrete structures using fibre composites.

Darby A., Ibell T., Clarke J., Denton S., Farmer N. and Luke S. Sep., 123-129

Infrastructure planning

Design of Garrion Bridge, Scotland. Fleck J., Chalmers B. and Todd D. Mar., 19-26 
Maintenance $\mathrm{Ct}$ inspection

Development of Eirspan: Ireland's bridge management system. Duffy L. Sep., 139-146

Llangollen Railway: refurbishment of Berwyn Viaduct. Symonds J. D. Sep., 151-161

The refurbishment of Heyeswood Railway Bridge. Dixon R. Sep., 131-137

\section{Management}

Development of Eirspan: Ireland's bridge management system. Duffy L. Sep., 139-146

\section{Materials technology}

Assessment testing Mizen Head Footbridge, Ireland. Ruane K. D. and Healy A. Sep., 117-122

Mathematical modelling

Evaluation of localised loading on suspension bridges. Wyatt T. A. Jun., 55-63

Railway systems

The Tay Rail Bridge disaster revisited. Martin T. and MacLeod I. A. Dec., 187-192

Rehabilitation, reclamation $\mathrm{Ct}$ renovation

Llangollen Railway: refurbishment of Berwyn Viaduct. Symonds J. D. Sep., 151-161

The refurbishment of Heyeswood Railway Bridge. Dixon R. Sep., 131-137

Repairs

Performance of repairs to concrete bridges. Tilly G. P. Sep., $171-174$

\section{Roads \&t highways}

Design and construction of Tongwamen Bridge, China. Zhang Z., Pan S.-S. and Huang C.-L. Mar., 1-7

Seismic design of Egnatia Motorway bridges, Greece. AhmadiKashani K. Jun., 83-91

Value of shock transmission units for Mumbai Bridge. Patel D. J. Dec., 203-212

\section{Safety Et hazards}

Comparison of slab-bridge safety assessment strategies. Imhof D. and Middleton C. R. Sep., 147-155
Strengthening rail bridge wingwalls for containment barriers. Clubley S. K. and Morey M. E. J. Sep., 163-170

Seismic engineering

Seismic design of Egnatia Motorway bridges, Greece. AhmadiKashani K. Jun., 83-91

Value of shock transmission units for Mumbai Bridge. Patel D. J. Dec., 203-212

\section{Statistical analysis}

Comparison of slab-bridge safety assessment strategies. Imhof D. and Middleton C. R. Sep., 147-155

\section{Steel structures}

HSFG bolted connections using weathering steel materials. Lark R. J. Jun., 103-110

Portrack, Scotland-a major railway realignment. Hackney M. J., Stocks A., Miller K. and Jencks C. Dec., 177-186

Strengthening fatigue-cracked steel bridge decks. Battista R. C. and Pfeil M. S. Jun., 93-102

\section{Strengthening}

Strengthening concrete structures using fibre composites.

Darby A., Ibell T., Clarke J., Denton S., Farmer N. and Luke S. Sep., 123-129

\section{Stress analysis}

Behaviour of post-tensioned concrete box girders. Lark R. J., Howells R. W. and Barr B. I. G. Jun., 71-81

Evaluation of localised loading on suspension bridges. Wyatt T. A. Jun., 55-63

Strengthening fatigue-cracked steel bridge decks. Battista R. C. and Pfeil M. S. Jun., 93-102

\section{Sustainability}

New bridge technology for sustainable development. Head P. R. Dec., 193-202

Tendering

Whole life cost analysis in concrete bridge tender evaluation. Arya C. and Vassie P. R. Mar., 9-18

Weather

HSFG bolted connections using weathering steel materials. Lark R. J. Jun., 103-110 